\title{
Miniature Objects of Cultural Covenant: Portraits and First Nations Sitters in British North America
}

\section{Kristina Huneault}

Volume 30, numéro 1-2, 2005

The Portrait Issue

La question du portrait

URI : https://id.erudit.org/iderudit/1069665ar

DOI : https://doi.org/10.7202/1069665ar

Aller au sommaire du numéro

\section{Éditeur(s)}

UAAC-AAUC (University Art Association of Canada | Association d'art des universités du Canada)

\section{ISSN}

0315-9906 (imprimé)

1918-4778 (numérique)

Découvrir la revue

Citer cet article

Huneault, K. (2005). Miniature Objects of Cultural Covenant: Portraits and First Nations Sitters in British North America. RACAR : Revue d'art canadienne / Canadian Art Review, 30(1-2), 87-100. https://doi.org/10.7202/1069665ar

\section{Résumé de l'article}

$\mathrm{Au}$ début du XIX ${ }^{\mathrm{e}}$ siècle, le portrait miniature fait partie d'une culture matérielle dynamique, au sein de laquelle les biens servent à la médiation et à la consolidation de liens de cordialité et d'appartenance sociale. L'analyse de ces processus a fréquemment comme contexte le milieu des élites métropolitaines britanniques et nord-américaines. Cependant, les ramifications culturelles du portrait miniature s'étendent bien au-delà de l'univers des Européens nantis. Jusqu'à 1840, parmi les nombreuses peintures qui évoquent l'Empire sur les murs de la Royal Academy, la moitié des portraits de non-Européens sont des miniatures.

Le présent article traite de trois oeuvres de ce type : le portrait du guerrier et diplomate mohawk John Norton, réalisé par Mary Ann Knight en 1805, et les portraits du ministre et diplomate ojibwé Peter Jones, peints par Matilda Jones en 1831 et 1832. Nous prenons pour point de départ l'hypothèse de Marcia Pointon selon laquelle « historiquement, les portraits miniatures relèvent essentiellement de l'oscillation entre le soi et l'autre ». En ce qui concerne l'Amérique du Nord britannique, les paramètres de cette oscillation révèlent des courants complexes d'assimilation et de différence, qui divisent les sociétés autochtone et blanche. Invoquant la notion psychanalytique d'objet transitionnel et les théories post-coloniales sur la traduction, cet article avance que les miniatures ont servi de gages tangibles, en étant les témoins d'une reconnaissance mutuelle au sein de rapports marqués par la différence culturelle et la violence coloniale. Par les conditions qui en marquent la commande et l'exécution, par l'histoire de leur échange et de leur circulation, ainsi que par leurs qualités propres en tant que représentations, ces portraits éclairent la dialectique singulière de l'attachement et de la séparation que met en oeuvre la miniature peinte.
Tous droits réservés @ C UAAC-AAUC (University Art Association of Canada | Association d'art des universités du Canada), 2006
Ce document est protégé par la loi sur le droit d'auteur. L’utilisation des services d'Érudit (y compris la reproduction) est assujettie à sa politique d'utilisation que vous pouvez consulter en ligne.

https://apropos.erudit.org/fr/usagers/politique-dutilisation/ 


\title{
Miniature Objects of Cultural Covenant: Portraits and First Nations Sitters in British North America
}

\author{
KRISTINA HUNEAULT, CONCORDIA UNIVERSITY
}

\begin{abstract}
Résumé
Au début du $X I X^{e}$ siècle, le portrait miniature fait partie d'une culture matérielle dynamique, au sein de laquelle les biens servent à la médiation et à la consolidation de liens de cordialité et d'appartenance sociale. L'analyse de ces processus a fréquemment comme contexte le milieu des élites métropolitaines britanniques et nordaméricaines. Cependant, les ramifications culturelles du portrait miniature s'étendent bien au-delà de l'univers des Européens nantis. Jusqu'à 1840, parmi les nombreuses peintures qui évoquent l'Empire sur les murs de la Royal Academy, la moitié des portraits de nonEuropéens sont des miniatures.

Le présent article traite de trois œuvres de ce type : le portrait du guerrier et diplomate mohawk John Norton, réalisé par Mary Ann Knight en 1805, et les portraits du ministre et diplomate ojibwé Peter Jones, peints par Matilda Jones en 1831 et 1832. Nous prenons pour point de départ l'hypothèse de Marcia Pointon selon laquelle « histo-
\end{abstract}

riquement, les portraits miniatures relèvent essentiellement de l'oscillation entre le soi et l'autre $»$. En ce qui concerne l'Amérique du Nord britannique, les paramètres de cette oscillation révèlent des courants complexes d'assimilation et de différence, qui divisent les sociétés autochtone et blanche. Invoquant la notion psychanalytique d'objet transitionnel et les théories post-coloniales sur la traduction, cet article avance que les miniatures ont servi de gages tangibles, en étant les témoins d'une reconnaissance mutuelle au sein de rapports marqués par la différence culturelle et la violence coloniale. Par les conditions qui en marquent la commande et l'exécution, par l'histoire de leur échange et de leur circulation, ainsi que par leurs qualités propres en tant que représentations, ces portraits éclairent la dialectique singulière de l'attachement et de la séparation que met en œuvre la miniature peinte.
I magine this: it is late on a Saturday evening in the April of 1805 and the candles are burning brightly in the windows of London's Somerset House. Many of England's most powerful and prestigious men have gathered together for the opening banquet of the annual Royal Academy exhibition. The Prince of Wales is in attendance, along with a string of dukes, marquisses, earls, lords, bishops, baronets, ambassadors, and lesser luminaries. Among them, is the unaccustomed and undoubtedly somewhat perplexing presence of John Norton: a thirty-four-year-old Mohawk war chief from across the ocean, whose accent is Scottish, whose manners are gracious, and whose conversation runs the gamut from the challenges of translating biblical texts into non-European languages, to the question of whether the Mohawk should have full legal title to the lands granted them by the British Crown. Norton has come to London to secure this title, and he is working the crowd, confident of his ability to charm. The popular novelist Walter Scott is clearly captivated, and Norton has had a personal assurance of assistance from William Wilberforce, the prominent anti-slavery parliamentarian. ${ }^{1}$ Here, warmly welcomed by the men who run an empire, he is optimistic of success. Perhaps, before he leaves, he takes a moment to visit the pictures. If so, he can hardly help but notice his own face looking back at him from among the dozens of miniature paintings on display (fig. 1).

Jump forward now, three decades: in a private home in the City of London, a visiting Ojibwe missionary named Kahkewaquonaby, or Peter Jones, poses for his portrait. ${ }^{2}$ A fastidious man, he wears the European clothing that he is now most comfortable in, and sits upright with his shoulders straight. The cold light of a late November day filters into the room, illuminating his face and the tiny ivory working surface of the miniaturist Matilda Jones (fl. 1825-43). ${ }^{3}$ Recently arrived from the backwoods of Canada, the sitter is a far cry from the family members that the artist usually paints, for in spite of the coincidence of their shared last name, the two are not related. They do, however, share a religious faith. Peter Jones is the rising star of the Methodist missions and soon to become Canada's first ordained Aboriginal minister. Possessed of the fervour of the convert and the energy of youth, he has persuaded his entire band to adopt Christianity and, along with it, English social organization and agriculture. ${ }^{4}$ His faith is both a profoundly personal choice and a highly politicized endeavour to secure land, education, and financial security for the Ojibwe. ${ }^{5}$ In pursuit of these latter goals, he has come to England on a fundraising tour. Matilda Jones's brother has been among the first in their evangelical circle to befriend him, and Matilda herself will soon act as intermediary in arrangements for Jones's private audience with King William IV. ${ }^{6}$ Over the course of the coming months, she will paint two versions of her miniature (fig. 2, 3). One will be found, many decades later, amongst the papers of Peter Jones and his English wife Eliza. The other portrait will be exhibited proudly by the artist in the 1832 Royal Academy exhibition. She will keep the portrait in her possession for the rest of her life, a memento of a remarkable man.

Together, these narratives capture the two functions most frequently associated with miniature portraits: public assertion of social identity and private token of affection. In the early nineteenth century, miniatures were part of a vibrant material culture in which possessions served to mediate and reinforce 
figure I. Mary Ann Knight, Captain Norton Teyoninhokarawen, a chief of the Mohawks, one of the Five Nations in Upper Canada, RA 1805. Watercolour on ivory, $9.2 \times 7.3 \mathrm{~cm}$ (oval). Ottawa, Library and Archives Canada (Photo: Library and Archives Canada $(-123841)$.



ings, and they travelled the globe sustaining personal and political ties across vast spatial expanses. Inevitably, many of their subjects were Europeans: military personnel, administrators, and emigrants to the colonies. Yet a look to the exhibition records of England's Royal Academy quickly reveals that the representational traffic was not unidirectional. Among the numerous paintings that charted the path of empire on the walls of the Academy prior to 1840 , fully half of the portraits of non-European sitters were miniatures. ${ }^{8}$

A few titles will give their flavour: in 1788 Portrait of Hussen Riza Khan, Prime Minister to the Nabob of Oude; in 1796 Portrait of Wy, alias Brown, a Native of Owyhee [Hawaii]; in 1801 Portrait of Mizra Aboo Taleb Khan; in 1818 Portrait of Raden Ràna Dipura, a Javanese Chief, in 1820 Shaik Mohamed, a Native of Bengal; in 1832 Kahkewaquonaby, an Indian Chief, and in 1838 Mustafa, an Egyptian Interpreter.

Such titles convey a sense of specificity quite unusual within the context of colonial representation. While European artists conventionally adopted strategies of anonymity and blatant fictionalization in their portrayals of non-European subjects, these miniatures offer precise and detailed recognition of individual identity. Their sitters are, by and large, neither denizens of some personal friendships and social belonging. To commission a miniature, to embellish, exchange or recognize it, was to participate in a process of creating and strengthening bonds that were borh affective and politicized. ${ }^{7}$ Typically, this process is assessed in the context of the ruling domestic elite who werc so often portrayed in miniatures: in England, the aristocracy; in North America, a wealthy class of businessmen, professionals, and their families. As the stories of John Norton and Peter Jones indicate, however, the political embeddedness of miniature painting extends beyond the sphere of white European privilege that is usually associated with the format, and enters into the thorny terrain of racial identity and colonial power relations.

For students of the interaction between European art and colonialism, miniature portraiture offers a largely unexamined trajectory of analysis. While their diminutive scale has made them easy to overlook, it was precisely their small size that rendered miniatures so particularly suitable to the exigencies of empire. These highly portable objects made easy ocean cross-
"Imaginary (Orient" nor prototypes for the "Imaginary Indian;") rather, they are men like Howqua, Senior Hong Merchant at Canton, China (RA 1831) and Captain Norton Teyoninhakarawen A Chief of the Mohawks, one of the Five Nations in Upper Canada (RA 1805). This specificity is suggestive. It raises the possibility that miniature paintings departed from the representational tactics of dehumanization that were so broadly useful to the colonial project. And so we might pose a question: did the miniature, despite its restricted physical confines, nevertheless encompass sufficient space for an encounter with difference that exceeded the boundaries of Otherness? ()r, more simply: do miniatures have a special potential to recognize the selfhood of another?

If such a potential exists, it is shared in part by all portraits. The face is a privileged avenue of access to subjectivity, and portraits are unusual in their ability to engender credence in the existence of a real individual who stands apart from the cultural and aesthetic overdeterminations that structure representation. 
Figure 2. Matilda Jones, Kahkewaquonaby, Reverend Peter Jones, 1832. Watercolour on ivory, $10.7 \times 8.0 \mathrm{~cm}$. Toronto, Victoria University Library, University of Toronto. (Photo: Victoria University Library).

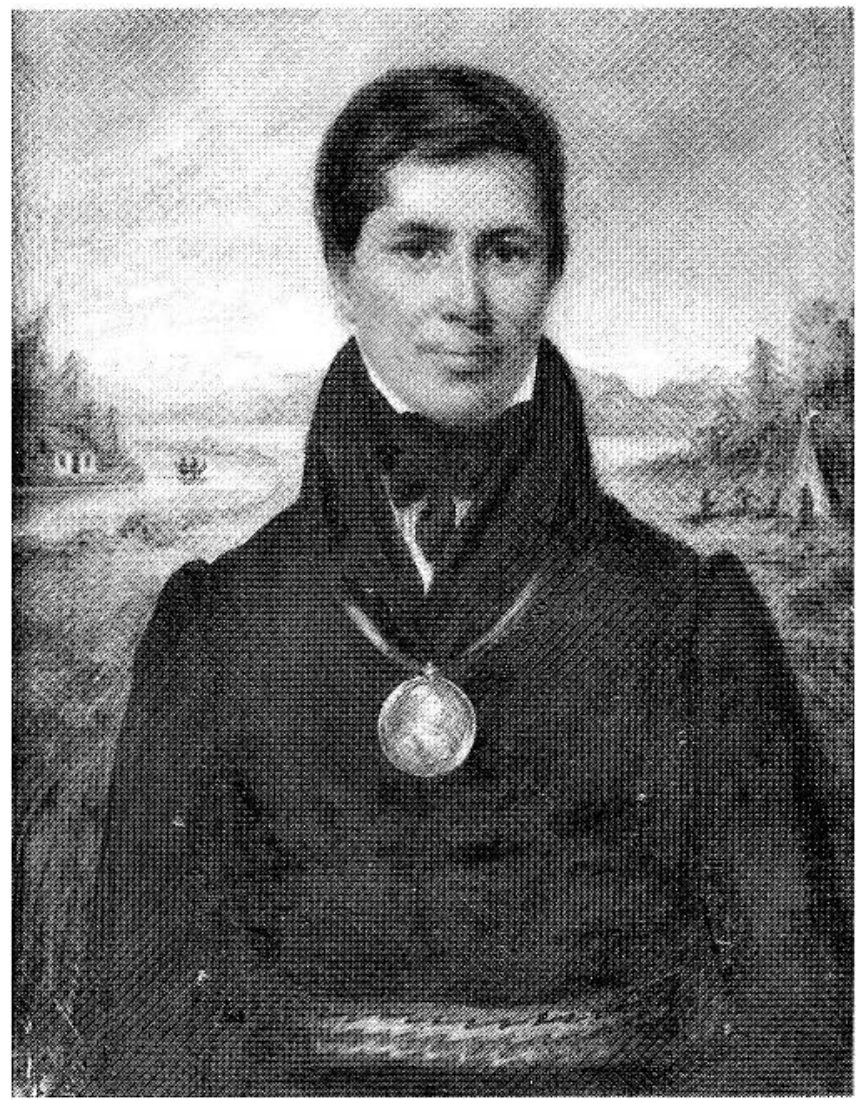

The moment we wonder of a likeness "who is that?," its subject has come forward to meet us on something like its own terms. When the painting in question is a miniature, however, this meering assumes a particular immediacy. To hold a portrait miniature in one's hand, to peer intently at its polished surface, to lower one's head and enter its world, is to be drawn into an intimate and intensely interior space. As the hand becomes the measurc of the miniature, scale creates a link with the body that reinforces the call to intersubjectivity, tying viewer and sitter rogether in an unusually proximate relation. The preciousness of the little combines with the affective eloquence of the body to endow the represented face with a special intensity of appeal, and through this appeal the miniature portrait speaks, however silently, of connection.

In British North America, the connective potential of the miniature extended even across the boundaries that functioned to separate colonized and colonizing cultures. Analyzing this phenomenon from the perspective of Aboriginal cultural production, art historian Ruth Phillips has called attention to the numerous miniature objects - not portraits in this instance, but tiny canoes, wigwams, and birch bark containers - that were produced by Iroquois, Mi'kmaq, and Anishnabe artisans for the
Figure 3. Matilda Jones, Kahkewaquonaby, an Indian chief, 1831. Watercolour on ivory. Ottawa, National Gallery of Canada (Photo: National Gallery of Canada).



emerging nineteenth-century tourist trade. ${ }^{10}$ Following on from the insights of anthropologist Claude Levi-Strauss and literary theorist Susan Stewart, Phillips draws on the almost universal appeal of tiny versions of larger objects in order to emphasize the special ability of the miniature to bridge cultural gaps by speaking to a shared sense of preciousness. ${ }^{11}$

A similar process may be discerned on the side of European cultural production. In this article, I will work with the English miniature portraits of John Norton and Peter Jones to demonstrate the ways in which these tiny watercolours on ivory also shared in the "particular suitability of the miniature to transcultural exchange." 12 The terms of that exchange point to the conflicted relations between Native and White socieries, to an oscillation between categories of self and other, and to the currents of assimilation and difference that divided colonial British North America. The portraits of Norton and Jones are marked by internal contradictions stemming from these often conflicting impulses. Despite this complexity, what I wish to say about the works may be summarized simply: they are covenants. In the circumstances of their commissioning and execution, in the history of their exchange and circulation, and in the material and representational qualities of the objects them- 
selves, these miniature portraits served as a tangible pledge of mutual connection across the gaping maw of cultural difference and colonial violence. Considered from the perspective of subjectivity, they may best be understood as shared promises of recognition and valuation.

There is a rather grim fittingness at work here; well might the promises of the colonial encounter be confined to a few square inches of ivory, fragile, little-noticed, and almost weightless outside their frames. Space, of course, was the primary spoil of colonial conquest, as Peter Jones himself made clear to a Scottish audience on a missionary fundraising tour in 1845 : "The Indian territories have been taken away till our possessions are now so small that you would almost require a magnifying glass to see them." 13 His words assume a disquieting art-historical resonance in the context of miniature portraiture. Given the relentless nineteenth-century encroachment on First Nations lands and the aggressive reduction of the cultural and symbolic space available to First Nations people, the aesthetic circumscription of Aboriginal subjectivity within the spaces of miniature portraiture carries the bitter aftertaste of historical aptness.

In face of the legacy of objectification and dehumanization that continues to traumatize First Nations, what credence can we give to claims of connection and mutual recognition, to talk of promises and pacts? I should say from the outset that I imply no idealization. ${ }^{14}$ As John Norton and Peter Jones had cause to know all too well, pacts can be broken, promises empty, and potential unfulfilled. While their youthful portraits commemorate the optimism of men whose ambitions to foster Aboriginal self-governance and welfare were still unthwarted, both Norton and Jones would live to see their endeavours undermincd or destroyed. The history of Aboriginal-European relations in Canada is a steady string of such betrayals. This is clear in retrospect. To those living through the colonial encounter, however, its outcome must have been considerably less certain, and the history of portraiture bears witness - at least occasionally to the moments of promise and possibility that this mecting also produced.

Such promise was born principally of friendship, as the history of John Norton's miniature attests. Norton's circle in London was composed of men who combined the intellectual curiosity of the Enlightenment with a commitment to civic life and a keen sense of social responsibility nurtured and expressed through nonconformist religious practice: men like the Quaker businessman Robert Barclay and members of the Clapham Sect of evangelical Anglican social reformers. In addition to William Wilberforce, Norton's supporters included Zachary Macaulay and Lord Teignmouth, both prominent advocates of colonial reform. Teignmouth would later assume governorship of India, but in 1804 his attentions were focused on the establishment of the British and Foreign Bible Society for the propagation of Christianity worldwide. The society's first published translation - of the Gospel of St John into Mohawk - was undertaken by Norton, who became fast friends with the Society's secretary, the Reverend John Owen. ${ }^{15}$ It was through Owen, in all likelihood, that Norton was introduced to the miniaturist Mary Ann Knight (1776-1851). ${ }^{16}$ His portrait was among those on which Knight chose to found her professional reputation, and in the coming years she would paint other members of the same social circle, including Owen himself, William Wilberforce's wife, and Robert Barclay's cousins. ${ }^{17}$ The Norton miniature was initially owned and probably commissioned by Mary Ansted, another of Norton's supporters, but at Owen's request she agreed to have it copied and to part with the original. ${ }^{18}$ The Reverend's fulsome thanks for the gift are effusive even by early nineteenth-century standards of inflated politesse, and they indicate his sincere pleasure at having Norton's miniature to treasure in the absence of the friend himself. ${ }^{19}$

Knight's miniatures were not the only portraits of Norton to be given in friendship. In February 1805, the Bath and West of England Society for the Encouragement of Agriculture, Arts, Manufactures and Commerce enthusiastically accepted Robert Barclay's gift of a large oil portrait of Norton, and ordered it to be hung in its main room. ${ }^{20}$ Norton had been elected to honorary membership on the occasion of his invited address to the Society the previous December, and his admission to its ranks indicates that he was welcomed as a fellow participant in the members' Enlightenment quest for knowledge and prosperity.

To be sure, this fellowship was not entirely free from a Romanticizing imperialist discourse. That much is readily apparcnt from another Norton portrait - this one a full-scale oil by Thomas Phillips (fig. 4). With its bared chest, prominent tomahawk, dramatic red costuming and far-off gaze, the canvas is of a piece with England's early nincteenth-century fascination with the exotic. This is the same Thomas Phillips, after all, who painted Lord Byron in Albanian dress. ${ }^{21}$ It bears noting, however, that the portrait's owner and commissioner, the Duke of Northumberland, perceived himself through a similarly Romantic lens. During the American Revolutionary war, Northumberland had fought together with Norton's adoptive uncle, the Mohawk leader Joseph Brant. The two men had become firm friends, and Northumberland identified with Brant and Norton as fellow warriors, signing his letters to them with the Mohawk name that he had earned through comradeship in North America. ${ }^{22}$ If this identification denied the vast and very real difference between those who owned England's land and those who were in the process of being evicted from it, it nevertheless established a common affective ground on which portraits could be given and received in a spirit of reciprocity. 23

Friendship, too, was the impetus for various portraits of 
Figure 4. Thomas Phillips, John Norton, ca. 1805. Oil on canvas, $88.9 \times 68.6 \mathrm{~cm}$. London, Syon House (Photo: by permission of His Grace, the Duke of Northumberland).

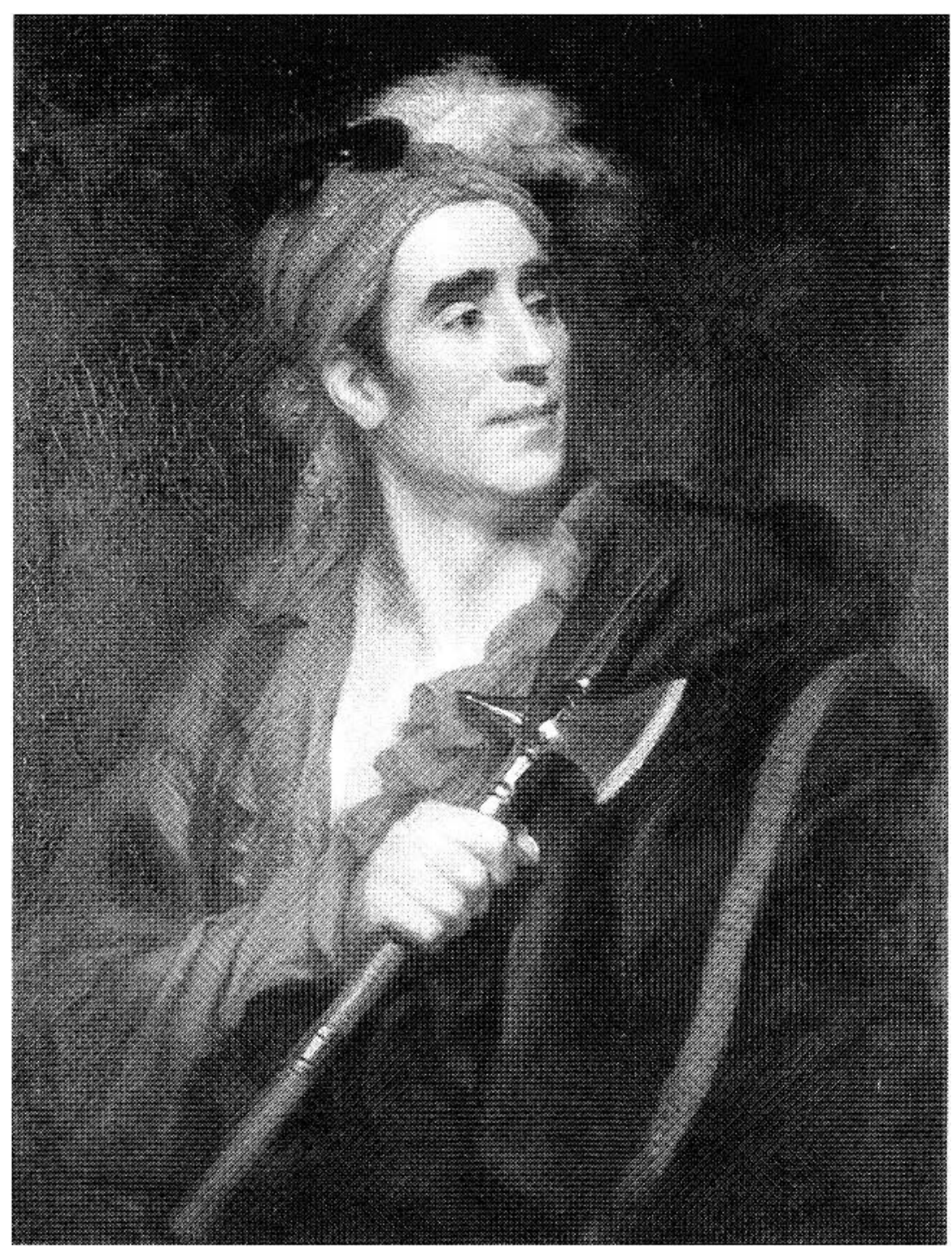

Dunlop himself and the other to be "a fine present" for Jones's family. In return for the gift, Eliza determined to embroider a pair of slippers for her husband's friend, and Jones dutifully took the measure of Dunlop's foot. While Jones's correspondence is tinged with the excessive deference that would characterize so many of his dealings with the British, a genuine affection towards his Scottish supporter is also apparent; Peter and Eliza were to give one of their sons the middle name Dunlop. ${ }^{27}$

The interpretive balance between personal affection and social power is difficult to strike, and I do not seek to obscure behind a rosy veil of friendship the very real inequalities that thwarted genuine closeness between Europeans and Aboriginals. The portraits of Norton and Jones were cnmeshed in a web of mediations between sitters, artists, owners, and viewers each of whom used the images in different ways, whether as political or religious tools, professional advertisements, personal mementos, or objects of affection. The various priorities are not always clear. What are we to make, for example, of this entry in Jones's diary: "Early in the morning a young gentlcman, a $\mathrm{Mr}$ Curlock, commenced taking my portrait for his own collection"? 28 Nineteenth-century European images of Aboriginal people were often the product of one-sided encounters that secured colonial power through the pictorial assertion of knowledge; while Mr Curlock's identity is now lost to history, the whiff of the ethnographic specimen collector is clearly in the air.

Peter Jones executed during his fundraising trips to Great Britain. On the third and last of these trips, Jones's letters home to his wife Eliza were full of references to his Scotrish friend and supporter John Dunlop. ${ }^{24}$ At Dunlop's urging and expense, Jones sat for his photograph, one copy for Dunlop, the other for Eliza, to whom Dunlop also sent a picture of himself. It was an involved process, and an artist was commissioned to add finishing touches from life. "I consent to all this fidgetty work," Jones wrote, "just to please my good friend Mr Dunlop, who is very anxious to have a good likeness of me." 25 Apparently, the result was not good enough, for later that month Dunlop persuaded Jones to have his portrait painted as well, at a cost of £5.5.0. Dunlop's enthusiasm was slowly infectious, and Jones soon wrote to Eliza: "My likeness is progressing[.] Mr Dunlop thinks it will be capital." 26 Again two copies were made, one for
It is tempting to effect the balance according to scale, with full-sized works weighing in on the side of colonial rhetoric, and miniatures corresponding to the countervailing pull of friendship. It is the full-scale oil by Phillips, for example, that exoticizes Norton most blatantly, while the miniature by Knight offers a more convincing sense of personal identity. Such a simple division is untenable, however, not least because miniatures sometimes served as the basis for the larger images. Matilda Jones's second ivory of Peter Jones, for example, was enlarged and engraved for the Methodist Church and subsequently published in the pages of the Wesleyan-Methodist Magazine (fig. 5). ${ }^{29}$ There is no firm archival evidence to indicate whether the miniature was commissioned principally from political and religious motivations (as a source for the Methodist engraving) or for private and romantic ones (the painting dates from the 
Figure 5. T.A. Dean (aitter Matilda Jones), Kahkewaquonaby, Peter Jones Missionary to the Chippeway Indians, 1833. Engraving, $11.4 \times 8.8 \mathrm{~cm}$ (image). Ottawa, Library and Archives Canada (Photo: Library and Archives Canada, e002282935).

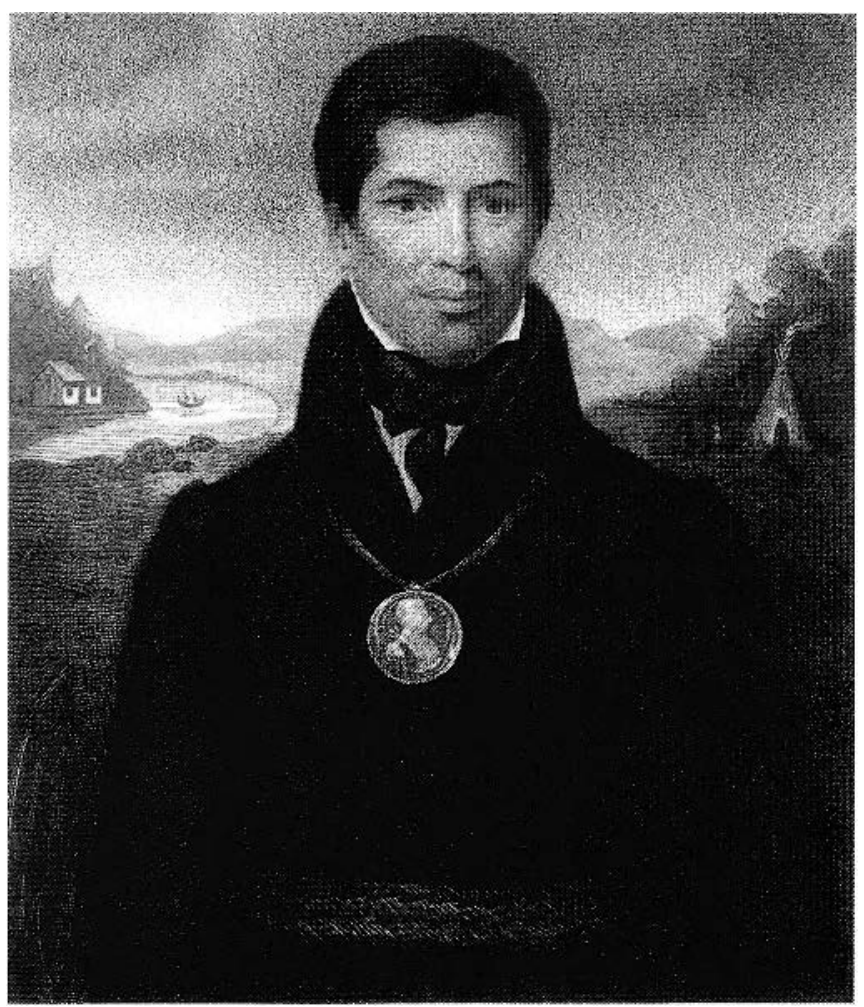

period of Peter Jones's 1832 courtship of Eliza Field, and was quite possibly intended as a present for her). Whatever the initial motivations, however, the miniature cannot simply be separated off from the blatantly political functions of the engraving, which served both as proof of the Church's success in its civilizing mission and as a prosclytizing tool among Canadian First Nations. ${ }^{30}$

If miniature portraits of First Nations sitters should not be naively positioned in the realm of pure friendship, the affective uses to which they were put were nevertheless profound. Let's stay for a moment with the second miniature of Peter Jones. Whether or not it was originally intended as a romantic token, Jones's wife Eliza was to cement the work's status as an object of love in 1838. Five years after her marriage, on a return visit to England from Canada, Eliza commissioned the same artist to execute a companion miniature of herself (fig. 6). ${ }^{31}$ Framed identically, the two miniatures were thus repositioncd as marriage portraits. Nor was it the first time that Eliza had used likenesses of herself and her beloved to strengthen the bond between them. During her separation from Jones in 1832, while Eliza convinced her reluctant parents to condone the unorthodox match, she visited the miniaturist William Gush (active 1833-74), who had previously painted Jones's portrait. ${ }^{32}$ On seeing this portrait in the studio, she resolved to have Gush
Figure 6. Matilda Jones, Eliza Field Jones, 1837. Watercolour on ivory. $10.3 \times 7.2 \mathrm{~cm}$. Toronto, Victoria University Library, University of Toronto (Photo: Victoria University Library).

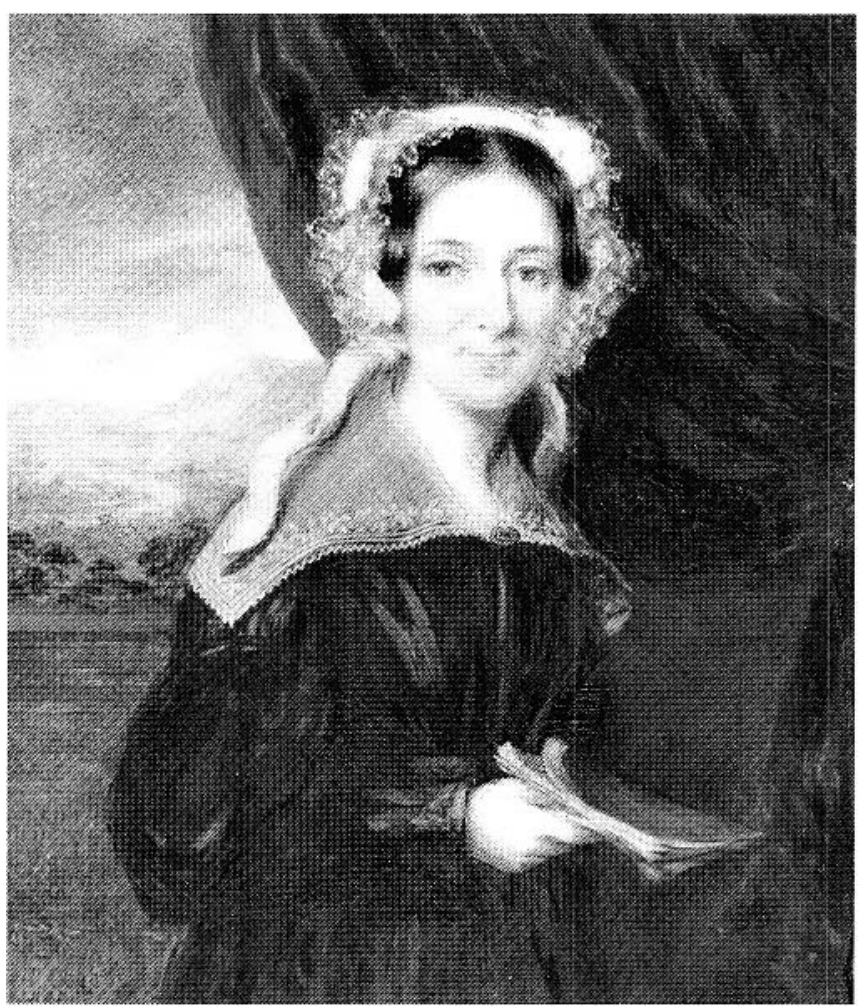

take her own likeness as a present to send to her fiancé in Canada, and she stuck to this resolution despite the "unpleasant ordeal" of nine separate sittings. ${ }^{33}$ Moreover, Eliza's fondest possession at this time was a likeness of Jones done by her own hand, and she mentioned this and other images frequently in her diary, from their creation ("Sketched my dear friend's face this morning"), to their refinement ("took a drawing lesson on the most interesting subject that ever employed my pencil"), adornment ("ordered a frame for my picture at Cooper's Piccadilly"), and display amongst her friends ("I ventured to leave with [Miss Brown] the likeness of my beloved K[ahkewaquonaby]. I shall long to see it safe back again, returned home in a fly."). ${ }^{34}$ Before Jones left England, the exercise of taking his likeness provided a blameless opportunity to spend time with him; once he was gone, his portraits served to keep him constantly in mind, and assumed a highly emotive charge. "Miss Brown called with my loved one's likeness," she recorded a few days later. "I welcomed it, but ah! It was not he." Or again: "Saw my dear love's likeness but it would not speak." 35

Melodramatic phraseology notwithstanding, Eliza Field's plaintive lament highlights the deep emotional attachment that could attend miniature portraits of First Nations sitters. Yet the words draw subtle attention to an oscillating affective thrust in which the longing for connection is offset by the reality of 
detachment. As objects of displaced affection, portraits of Jones both united Eliza with her lover imaginativcly and emphasized his physical absence. Such a dynamic is not unique to miniatures of First Nations sitters, but it will be of special importance to them, and it is here that I wish to begin focussing my analysis on the miniatures as such, in an attempt to assess the format's special function within the colonial context.

The miniature's connective potential as an intimate and corporeally charged object should, by now, be clear. This is only part of its reality, however. The phenomenological effects that miniature paintings engender are, in fact, caught between intimacy and detachment, or, in the influential language of Susan Stewart, between immanence and transcendence. ${ }^{36}$ On one hand, the immanence of the miniature is palpable, for its intimate aesthetic space is closely allied to the body. And yet the miniatures engrossing material presence is multiply undermined, not only by the culture of physical separation that occasioned nineteenth-century miniatures (through wars, emigration, and mercantile expansion) but also by the position of transcendence that viewers assume in rclation to them. Beholders tower over the tiny objects, dominating them physically, and the effect of this is to underline viewers' separation from the little world that so persuasively draws them towards it. Like the fairytale appeal of Thumbelina's walnut-shell cradle and rose-petal blanket, the attractive power of the miniature is matched only by the poignancy of its inaccessibility. Thus, through a dialectical play of proximity and distance, the miniature induces a bittersweet recognition of boundaries. The effect is reinforced by the physical frame or casing that delimits the object's edges and retains an assertive presence within the beholder's field of vision. In the case of portraiture, these boundaries are rehearsed at the level of the subjcct. We can come infinitely close to the other individual that the miniature portrait represents, while always remaining separatc. Marcia Pointon does the dynamic justice when she writes that miniature portrait objects are "historically, quintessentially, about the oscillation between self and other." ${ }^{37}$

In the case of the Norton and Jones miniatures, such self/ other rclations are inseparable from the context of early nineteenth-century British North America, where the question of boundaries had assumed tremendous urgency. The outlines of Britain's geopolitical presence in North America were most famously forged in war, and in relation to well-defined enemies: first the French (the Seven Years War), and subsequently the Americans (the American Revolutionary War and the War of 1812). But these most bellicose articulations of the physical boundaries of English colonial identity were effected on terrain that was already occupied, and by people whose relation to the English was far less clearly defined. During the period spanned by the Norton and Jones miniatures, 1805 to 1832, North American First Nations were variously military allies and mili- tary threats, expedient political pawns and a serious obstacle to settlement, independent nations and subject peoples. At some times, and particularly between 1783 and 1812, the British went so far in their alliance with the Iroquois as to encourage the establishment of an autonomous Aboriginal nation state, to serve as a buffer zone against Amcrican expansionist tendencies; at other times Native peoples were driven from their lands and deceived in their trust with an arrogance and rapacity that beggars imagination. John Norton in 1805 and Peter Jones in 1832 each rcpresented peoples who were reeling in the wake of territorial dispossession. Though they had fought as Britain's staunchest allies in the American Revolutionary War, the Mohawk had been betrayed at the Treaty of Paris in 1783, when the boundary between Canada and the United states was drawn indiscriminately through Iroquois territory. The Mohawk, mistrusting Amcrican intent towards them, were obliged to leave their ancestral lands, and many relocated on a strip of Canadian territory recently purchased by the British from the Ojibwe. That sale had been only part of a much larger appropriation of Ojibwe lands. Acting under misapprehension of British intent and without a concept of private land ownership, the Ojibwe had begun surrendering their lands to the British Crown in the 1780s. ${ }^{38}$ The results were traumatic: animals were annihilated, and along with them the food supply; imported diseases ran rampant among a population with no natural immunity; alcoholism followed on the heels of despair. In the decade preceding Peter Jones's birth, his mother's band was decimated by fully one third. ${ }^{39}$ By 1820 , the entire ancestral lands of the Mississauga band that Jones was born to had been reduced to 200 acres less than one third of a square mile - over which they had no firm title. ${ }^{40}$ Both tracts of land, Mohawk (Iroquois) and Mississauga (Ojibwe), were far too small to sustain hunting and fishing, and the adoption of European agriculture, together with the social organization it entailed, rapidly became the only possible means of survival.

In the face of such crisis, then, the miniacurc's address to the oscillation between self and other becomes particularly fraught. The questions are complex: how to negotiate the boundaries of the self at a time when the material foundations of Aboriginal identicy had been taken or destroyed, and when survival itsclf seemed to hinge on assimilation to the way of life of an other whose rhetoric of friendship and alliance was maintained and upheld even in the face of betrayal and usurpation of resources? How, moreover, to make sense of that betrayal when, at the personal level, genuine bonds of esteem, friendship, and indeed love, existed between individuals of each culture? How, finally, to even comprehend identity when the realities of intermarriage had already begun to blur the boundaries between Aboriginal and European subject positions?

Both John Norton and Peter Jones were of mixed parent- 
age. Norton's mother was a domestic servant from Fife, in Scotland, and his father was a Cherokee from Carolina who had been brought to Scotland as a child after the burning of his village by British military forces. ${ }^{41}$ In Jones's case, the marriage patterns were more typical of the colonial situation: his mother was Ojibwe, the daughter of a Mississauga chief, and his father was a Welsh surveyor, the advance guard of European settlement. Both Norton and Jones developed an intimate familiarity with the languages, beliefs, and customs of their dual Aboriginal and European cultures. At a time of unprecedented social transition, each man assumed the position of translator. It was, indeed, as a translator employed by the Indian Department that Norton had come to Joseph Brant's attention, and been adopted into the Mohawk nation to serve as Brant's political lieutenant. Translation, too, was at the heart of Jones's missionary work; his renditions of English hymns into Ojibwe were central to religious life among Mississauga Christians. Both men translated parts of the Gospels for the British and Foreign Bible Society.

In undertaking such acts of linguistic conversion, Norton and Jones were active participants in one of the most complex practices of intercultural contact. The miniature's status as a kind of go-between that mediates self-other relations is paralleled by the cultural work performed by the sitters themselves, for translation is precisely such a mediation. To translate is to participate in an intimate encounter with a form of cultural alterity (in this case a foreign language) that asks simultaneously to be recognized on its own terms and to be rendered comprehensible in the terms of another. The position is potentially paradoxical, but for social anthropologist Vincente Rafael the contradiction is resolved by the relations of power that frame all acts of translation. One's words, in translation, Rafael points out, are subordinated to the codes and structures of the target language; one's thoughts and actions are reshaped "in accordance with accepted forms." For this moment of subordination, however, there is always a payoff: "If translation is to take place at all, it must do so in the context of expectation: that in return for one's submission, one gets back the other's acknowledgment of the value of one's words and behaviour. In this way, one finds for oneself a place on the social map." 42 Little surprise, then, that translation has always been an "indispensable channel of imperial conquest and occupation." $\$$.3

But if submission and recognition are the reciprocal axes of translation's social map, the untranslatable quality that every language preserves functions in resistance to the attempt to transform it, and suggests that the movement of power and submission is not exclusively unidirectional. Gayatri Spivak's writings on translation underline this possibility for power reversal. For Spivak, the surrender involved in a skilful translation is not only that of the source statement to the codes of the target language, but of the translator too (as agent of the target lan- guage) to the rhythms and nuances of the source, which demand recognition in their full complexity:



No amount of tough talk can get around the fact that translation is the most intimate act of rcading... We have to turn the other into something like the self in order to bc ethical. To surrender in translation is more erotic than ethical. ${ }^{4 / 4}$

Though her language is characteristically dense here, Spivak's terminology may helpfully be unpacked and used to describe the conceprual context in which the miniatures of Norton and Jones functioned. Like the translators that they represented, these portrait objects mediated between subject positions, both in the public domain of geopolitical power and social organization, and in the private sphere of friendship and love. In each case, the challenge was to negotiate the distinction that Spivak frames in terms of ethics and erotics - on the one hand, the commonality established by translating otherness into selfhood (and so creating the emparhetic base from which ethical action may proceed), on the other, the distinction preserved by meeting difference on its own ground (and so maintaining the scparation within which desire can operate). How did this process of mediation play out across the complex field of intercultural encounter within which the miniatures were situated? How can we understand the portrait object's role in the processes of identification and differentiation that made their sitters so complex? To begin to answer these questions it will be useful to look more closely at the portraits themselves.

John Norton's miniature (fig. 1) bears witness to the complexity of colonial subject positioning. Its visual cues are strongly transcultural. Norton's long face, with its narrow nose and curly sideburns, is distinctly European, but his dress is emphatically not - or at least not initially recognizable as such. Boldly theatrical in tone, the miniature's air of sartorial flourish might give rise to suspicions of artistic license were it not for a description of Norton's appearance at a soirée at Cambridge University, where he regaled the men of Trinity College with a memorable evening of Iroquois stories, songs, and dances. A manuscript account of the evening substantiates the details of the dress Knight has painted:

a chint7. handkerchief was bound about the head under which was a piece of red silk of the same texture as our officer's sashes on one side was put an ostrich feather ... Now to describe his shirt; it was made of blue Calico with small streaks of white in it ... closely studded with silver broaches ... Over the shirt upon state occasion is thrown a loose unornamented and unhemmed piece of cloth ... There were 
depending from his cars large silver earrings, this was the only part of the dress that I would wish omitced, as it was the only article that reminded you of a barbarous, that is an uncivilized nation. I asked whether they all wore ostrich feathers, as ornaments in the head, he said that a warrior would not unfrequently wear the wings of an eagle, or any orher crest of that sort. ${ }^{45}$

Chintz, calico, military silk: the Mohawk had been trading with Europeans since the mid-sixteenth century, and the silver jewellery so unpalatable to the eyes of the Cambridge gentleman was, in fact, a symbolically significant currency within that exchange. ${ }^{46}$ After silver, the African ostrich feather, which captured the curiosity of Norton's interlocutor, was among the more prestigious trade goods available to chiefs in the Eastern woodlands, who used elaborate items of fancy dress to signal their efficacy in negotiating with Europeans and to demonstrate their ability to obtain the best possible terms of exchange for their Native constituencies. ${ }^{47}$ Norton's adoption of what appears to be a British military collar suggests a clear understanding of the forces that called the shots in that relation, but his adaptation of European military dress according to Mohawk conventions gives equally clear notice of his determination to shape the process of cultural contact. Self-possessed and worldly, Norton looks out from the miniature, his watchful but heavily-lidded eyes suggesting an alert intelligence behind a veneer of sleepy complaisance. A smile plays at the corners of the mouth and hints at a knowledge shared but not spoken of. There is a slight suspicion of irony, a stronger impression of decisiveness, and an air of acumen entirely befitting a man whose trip to London was, in effect, a savvily attempted end run around Canadian colonial administrators. These administrators acrimoniously and, in the end, successfully opposed Norton's efforts, but while he was in London, Norton throve on the positive attention that his transcultural position helped secure for him in the seat of European power.

It is a very different man who stares forth from the portrait of Peter Jones that he and Eliza treasured (fig. 2). The dual cultural identity that underwrote Norton's miniature is, in Jones's case, asserted with agonistic didacticism: around his waist the sitter wears a finger-woven sash of Native origin; around his neck hangs a medal of King George III. But if the transcultural message is the same, its terms have been significantly shifted. Despite the nominal balance between Native and European elements (sash and medal) the whole is dominated by the pictorial hegemony of the black European topcoat. Where John Norton's silver earrings and brooches stood as markers of exchange between trading partners, Peter Jones's medal was granted him by the Indian Department, along with a Union Jack, in confirmation of his status as chief. ${ }^{48}$ The medal thus marks
Figure 7. J. Thomson (after W. Gush), Shahwundais, Revd. John Sunday. A Converted Chippeway Chief, n.d. Engraving. Ottawa, Library and Archives Canada (Photo: Library and Archives Canada, e002291389).

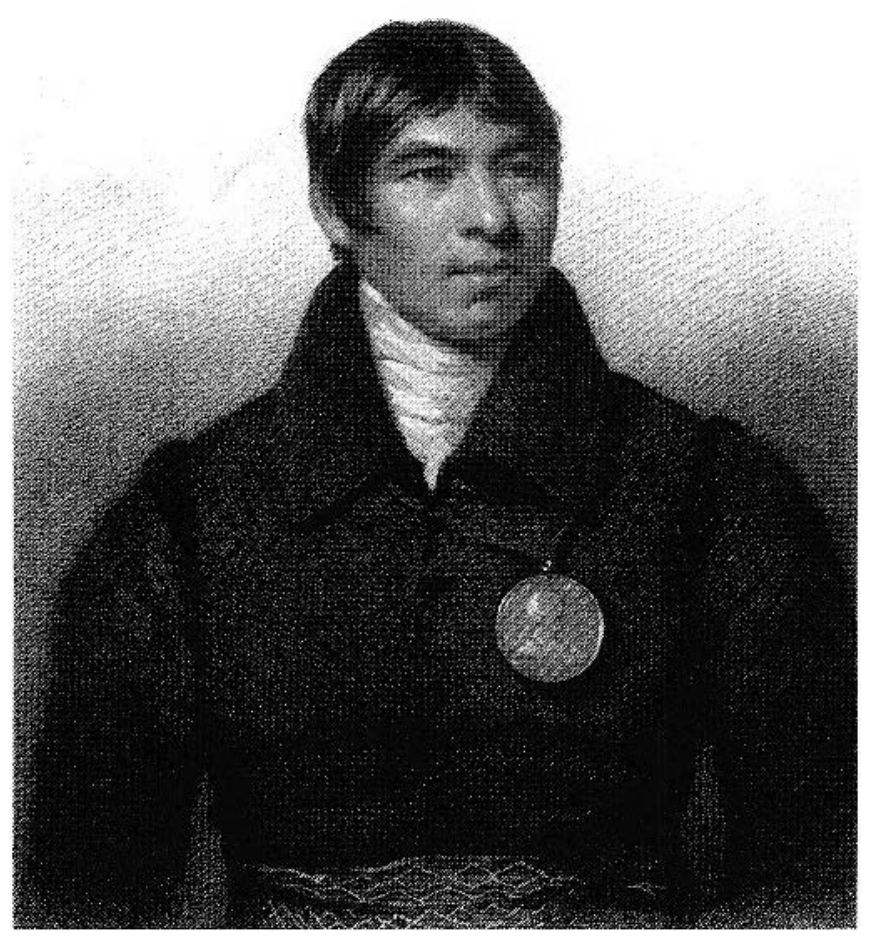

British intervention in Native governance, and signals loyalty to the Crown. Moreover, through its mobilization of a kind of "miniature-within-a-miniature" motif, the medal also stands in a quite different spatial relation to subjectivity than the silver worn by Norton. Whereas Norton's blanket of brooches remains unequivocally on the surface of his shirt, the mise-enabyme set into play by Jones's silver medal fosters an interiority that instates the body of the English King at the very heart of the sitter. ${ }^{49}$ Talk of hearts and bodies here is no mere rhetorical convenience - or at least it is not my own, for Peter Jones publicly referred to the chiefs' medals as "their hearts." 50 The metaphor is given pictorial literalism in an engraving of one of Jones's most important converts, the Ojibwe chief John Sunday, whose medal defies gravity to hang, off-centre, over his heart (fig. 7). ${ }^{51}$

And then there is the background. Again, the message of dual cultural heritage is explicit: on the left side of the figure a settler's log cabin, on the right an Aboriginal wigwam. The only surprise is that the two vignettes are not reversed so as to read from left to right in an evolutionary narrative of acculturation. Such a narrative is apparent, however, in the two different versions of the miniature itself - the 1831 original owned by Matilda Jones (fig. 3) and the 1832 copy belonging to Eliza and Peter Jones (fig. 2). Comparing the two portraits, Jones's biogra- 
pher, Donald Smith, asserts that Jones looks more European in the later ivory. ${ }^{52} \mathrm{He}$ certainly seems more proper. A generous word would be decorous, a less forgiving one would be domesticated. Beyond the obvious neatening of the hair, the whole body has been slightly turned to the front: made direct, open, decent. Look at the difference in the mouths: the same full lips appear in both, but where the 1831 version is relaxed in an almost voluptuous curl, the smile in the 1832 miniature is tighter, more uniform. Other differences in the face are harder to identify (a shadow at the basc of the chin in the Toronto version, for example, suggests a forward tilt of the head, just slightly more deferential) but their effect is nonetheless pronounced. The Peter Jones of 1831 is Romantic, almost dashing; the Peter Jones of 1832, priggish and didactic. To push the contrast into caricature: swashbuckler and schoolteacher.

The creeping tightness in the 1832 miniature is doubtless partly the product of its status as a copy. Jones's diary makes mention of sitting only for the first portrait, and the extreme similarity of the background configurations makes it likely that the artist was working from the painting rather than life when she made the second miniature. Some loss of vitality is thus to be expected. Yet it is this version of Jones that appears on the cover of his biography, and the choice is not unjust, for it is this more wooden Jones who emerges from the pages of the biography and the archives alike: the Jones who met his self-described "carnal mind" with a rigid and daily schedule of prayer and selfdenial; the Jones whose insistence on English discipline sparked a rebellion amongst Ojibwe parents who refused to permit corporal punishment of their children in school; the Jones who upheld private land ownership in the face of its devastation of the Ojibwe nation. ${ }^{53}$ This is the Jones whose 1832 address to King William IV was framed in the heartbreaking language of the assimilated:

Whon the great Spirit found us, we had no fields, no houses, no Cattle, and were altogether destitute of the comforts of this life, but since our eyes have been opcned to see this good way, we have been very anxious to have lands to cultivate, to have houses to live in, and to enjoy all the blessings \& comforts that our white Brethrens enjoy, and to live like the good white farmers. ${ }^{54}$

Where John Norton embraced his Aboriginal identity abroad, appearing with evident pleasure in his Mohawk dress, Jones would grow to despise his "odious Indian Costume," which he donned reluctantly because the curiosity it engendered amongst the British helped him raise funds during his "begging" tours. ${ }^{55}$ Jones was extremely conscious of his public image, and another difference between the two portraits - the substitution of a white collar for the black neck treatment - suggests that the copy might well reflect Jones's own preferred self-presentation, for in a letter to Eliza, he commented on his greater success in fundraising when wearing white at his throat: "I think that by this time you must be convinced that there is nothing like white divinity for the neck of your swarthy husband. I was hard at work yesterday begging, but as I had on my black stock I only received $£ 7 . "{ }^{\prime 6}$ The quotation signals Jones's acute sensitivity to English expectations of him along with his desire to accede to them, but the false levity of his reference to "your swarthy husband" strikes a painful note and suggests an equally acure awareness of the distance that must ever separate him from the culture he so fervently sought to emulate. In his miniature, Jones's body itself would come to represent this distance, decisively separating cabin from tcpee.

The two miniatures, then, suggest their sitters' very different attitudes towards European acculturation. While both men undertook translations for the British and Foreign Bible Society, Norton was eventually to abandon the task as not meeting Aboriginal needs. ${ }^{57}$ While both recognized that adaptation to settlement was inevitable, Norton was to grow less and less sanguine about its possible benefits to Aboriginal society. "Unfortunately," he wrote in the margins of a letter from the American Board of Commissioners for Foreign Missions, "the approach of Christian Settlements destroys the temper of mind necessary to receive the seeds of Christian morality ... [and] though it does not civilize yet it certainly subjugates to subserviency and vice the wildest of the tribes." ${ }^{8}$ Where Norton continually defied authority (deserting the British Army in his youth, waging diplomatic warfare with the Indian Department in his maturity), Jones more often sought to subject himself and others to it (the concepts of $\sin$ and redemption were ones he rode hard in his sermons; he opposed consensus governance as time-consuming and old-fashioned). Where Norton had a vision of panIndian federation, Jones was caught up against his will in the divisive sectarian arguments within Canadian Methodism. Where Norton urged chiefs to use the term Brothers, not Father, in their address to the English, Jones had largely given up the battle.

From a postcolonial perspective, it is hard not to prefer Norton - implacable foe of the forces of assimilation. Such a comparison is somewhat unfair, however, for it does not account for the tremendous differences in the two men's situations. Temporally, Norton and Jones lived on opposite sides of the War of 1812 - a war in which First Nations had been the only undeniable losers, as their strategic position within the balance of power was neutralized by the stabilization of North America's geopolitical boundaries. Geographically, the two men had been born on opposite sides of the ocean. Raised and educated in Scotland, Norton's eagerness to abandon his European identification was born partly of his confidence in its 
fundamental inalienability. Jones had no such confidence; his formative years had been spent amongst the Ojibwe, and his forced acclimatization to European culture came late, when his father, alarmed by the devastation that settlement had wrought among the Ojibwe, assumed custody of his two teenaged sons. At roughly the same age that John Norton was able to shed the controls of the British Army and the English education system in favour of a life of trading and hunting, Peter Jones was pushed in the opposite direction by threat of starvation. Living with his father, the sixteen-year-old boy received a crash course in cultural indoctrination. He was baptized, educated to read and write English, and, above all, taught to value the agricultural development of private property. In short, whereas John Norton had become Teyoninhokarawen, Kahkewaquonaby became Peter Jones.

The assimilationist message that Augustus Jones drummed into his children was mixed with constant reminders of the ultimate impossibility of that aim, however. On the death of Peter's half-sister, Elizabeth, Augustus wrote to his son in fond remembrance of the young child: "She used to ask am I English we said No, What am I then? You are a little Indian Girl, She would say O, I wish I was English they are a fine people." Like her brother, Elizabeth was of mixed parentage - as much British as Indian - but in British North America there was no way to pull these identities together. Peter Jones tried as hard as anyone to do it, but the strained appearance of his portrait, and the agonistic nature of its iconography, reveal the tremendous price that the dual subject was forced to pay. The sense of Peter Jones that emerges from his writings and his biography is of a man who held himself together through force of will, of prayer, and of discipline, but the essentially fragmented nature of his subject position emerges in representation. It does so most clearly in the engraved version of Matilda Jones's miniature (fig. 4). Below the image, the sitter's two names are inscribed: The Rev. Peter Jones and Kahkewaquonaby. Both names have the appearance of signatures, but the handwriting is completely different: one a flowing, forward-slanted hand, the other a harsher script that runs straight up and down. Like Dr Jekyll and $\mathrm{Mr}$ Hyde, the Reverend Peter Jones and the Indian Kahkewaquonaby were irrevocably divided, even at the very points - name and signature - that have, historically, served as markers of identity.

This delicate and painful balance of division and unification brings me back, one last time, to the touchstone of this essay: the contention that miniature portraits are "historically, quintessentially about the oscillation between self and other." 60 I have argued that the phenomenology of the miniature enacts a bittersweet dialectic of intimacy and detachment; while its tiny scale forges a special relation of closeness with the viewer, the beholder's physical position is also, and inescapably, one of transcendence. In elaborating the implications of this insight with respect to the structures of subjectivity, Marcia Pointon has skilfully drawn out the miniature's status as a transitional object. Pointon uses the term in its psychoanalytic sense, as something that affirms the position of the subject by insisting that "its bearer is at one and the same time socially attached and individually separate." ${ }^{61}$ Miniature paintings of First Nations sitters in British North America present a persuasive case for extending Pointon's insight from the sphere of viewer (or bearer) to that of the sitters themselves. Considered within their subjects' colonial context, these miniatures now become not only transitional objects, but also translational ones. The significance of this shift in terminology will carry me through to the conclusion of this article.

John Norton and Peter Jones were two men, translators both, who lived the crisis of the colonial subject with all of its attendant uncertainty of boundaries. Both used their miniatures to forge personal and social identities that could operate across the cultural divides that they straddled, and in this sense their likenesses operated within the context of expectation that Vincente Rafael posits as the basic premise of translation: that in exchange for presenting oneself within the cultural codes of another representational system, the subject can reasonably expect the other's acknowledgement, and thus a place on the social map. To place the miniature within the sphere of translation is, accordingly, to stake a claim for it as an object of cultural covenant. A promise. Because of their different historical positions, the terms of that covenant were quite different for Norton than they were for Jones, but together the men's likenesses encompass both poles of the miniature's transitional function that is, as an agent of both attachment and separation. For Jones, the emphasis was, above all, on attachment to the dominant social group; he sought to secure both personal identity and the welfare of the Mississauga people through a belonging based on acculturation to British norms. For Norton, the focus was less on belonging than on recognition, both of Mohawk autonomy, and of his own individual character. Such recognition is a process that presupposes a separation between self and other, for recognition requires the detachment of an independent point of observation. In its transitional and its translational functions, then, the colonial miniature had the capacity to serve the ends of both Spivak's ethics and her erotics: the transformation of difference into sameness, which we might figure as attachment, and the embrace of difference on its own terms, which is founded on separation.

The unification of these two positions - so delicate and so difficult - is as critical for individuals seeking to live together with orhers as it is for cultures trying to coexist in the same territory. Though resolution effectively exceeded their grasp, the participants in the British North American colonial encounter 
were fully cognizant of the nature of the challenge. That they understood it in terms not so very different from those I have used here is suggested by the metaphors that structured the earliest form of cultural covenant between First Nations and European settlers. Dating from the late seventeenth century, the first instance of formalized transcultural diplomacy was effected through the assistance of two visual images, which, when taken together, constituted the first treaty, dedicated to establishing the tenets of friendship and peaceable coexistence between peoples. For the Onkwehonweh, or "the People" of the Iroquois confederacy, these principles were pictorially embodied in Kaswentha, a wampum belt with two rows of purple shells symbolizing two boats, one Native and one newcomer, each travelling side by side in mutual respect and non-interference. ${ }^{62}$ For the Dutch, and the English who followed them, the symbol was the Covenant Chain: a chain first of rope, then of iron, and finally of silver that bound the two peoples together in bonds that could neither break nor rust. Though it partakes of the metaphor of covenant that I have used to structure my discussion thus far, the addition of the word "chain" changes the term's inflection significantly, adding to mutuality an element of inescapable determination. Where Kaswentha offers the harmony of parallel lines that never cross, the Covenant Chain represents the rewards but also the perils of lives bound inextricably together. To preserve the clarity of the visual, we might diagram the two metaphors thus:

\section{$\begin{array}{ll}= & 00 \\ \text { Kaswentha } & \text { Covenant Chain }\end{array}$}

Each culture accepted the other's symbolism, but the images themselves represent very different ways of conceiving the terms of a relation between self and other: the first is based on separation and distinction, the second on connection and unity. The wampum's clarion call is for mutual respect, dignity, and integrity, but it is based on a clarity of identity that was impossible to maintain in a post-contact world. The chain captures the interconnectedness of peoples, whether social, economic, political or psychological, but it remains a potential instrument of bondage and coercion. Trouble was unavoidable from the beginning. One version of Iroquois oral history has it thus:

The whiteman said, "What will happen supposing your people will like to go into my vessel?» The On-kwe-hon-weh replied, "If this happens, then they will have to be guided by my Canoe." ...

The whiteman said, "What will happen if any of your people may someday want to have one foot in each of the boats that we placed parallel?" The On-kwe-hon-weh replied, "If this so happens that my people may wish to have their feet in each of the two boats, there will be a high wind and the boats will separate and the person that has his feet in each of the boats shall fall between the boats; and there is no living soul who will be able to bring him back to the right way given by the Creator, but only one: the Creator himself." 63

John Norton and Peter Jones, Teyoninhokarawen and Kahkewaquonaby, exemplify this precarious position. As realists they recognized the impossibility of cultural isolation; as idealists they refused to link that recognition to resignation, and both men worked to shape the fortunes of their nations. Each man's work assumed a different orientation: for Norton, raised and educated as a European, the recognition of the rights and claims of difference would be paramount; for Jones, given no choice but to assimilate into the regime of his father's European life, the emphasis would be on belonging and sameness. Considered together, the two men might thus be taken to embody opposite approaches to colonial coexistence, and their represented portraits go some way to confirming this: Norton, self-confidently arrayed in Mohawk dress; Jones, deferential in a frock coat. Yet both men were translators, and their miniatures - when they are considered as miniatures - may both be situated in the transitional space of intersubjectivity that complicates such clear divisions. As transitional objects, shuttling back and forth between self and other, Norton's and Jones's portraits each play out the miniature's special dialectic of connection and detachment. In the end, the works are most eloquently a negotiation of this dialectic. Taken together, these miniature portraits may be understood as optimistic assertions of belief: that it will someday be possible to live according to the principles of both Kaswentha and the Covenant Chain; that connection can be made without loss of autonomy; that belonging may be achieved without subservience. Neither man was fully able to realize this vision, and it remains for us to determine whether the belief can be justified.

\section{Acknowledgements}

I am fortunate in the support of the Social Sciences and Humanities Research Council of Canada and the Fonds québécois de la recherche sur la société et la culture, and more fortunate still in my colleagues, students, and friends. My warmest thanks are due to David Capell, Brian Foss, Avery Larose, Ruth Phillips, Johanne Sloan, and Donald Smith.

\section{Notes}

1 For accounts of the banquet and its attendance, see the Daily Advertiser, Oracle, and True Briton, 29 April 1805, n.p., and the 
Morning Herald, 29 April 1805, n.p. The principal work on Norton is Carl Klinck's "Biographical Introduction," in Carl Klinck and James Talman, eds, The Journal of Major John Norton (Toronto, 1970), xiii-xcvii. Except where orherwise indicated, I am indebted to it for all biographical information on Norton.

2 I will generally refer to both men by their English names. In Norton's case, the rationale for the choicc is fairly clear: John Norton was the sitter's birth name, and Teyoninhokarawen is more accurately a title than a name, conferred on him upon his election to chiefdom. For Peter Jones, the choice was more difficult, and an earlier version of this paper used his birth name, Kahkewaquonaby, throughout. It seemed to strike a false note, however, for the paper deals primarily with the terms of Jones's relation with the English, and in thesc dealings he appears generally to have preferred his English name. I have respected this preference.

3 The sitring took place on 25 November 1831 in Matilda Joncs's home at Number 8 Coleman Street. See Peter Joncs, Life and Journals of Kah-ke-wa-quo-na-by (Rev. Peter Jones) (Toronto, 1860), 305.

4 See Donald Smith, Sacred Feathers: The Reverend Peter Jones (Kahkewaquonaby) and the Mississauga Indians (Toronto, 1987). Smith's book is the principal work on Jones and I have relied on it except where otherwisc indicated.

5 The 1831 work, which is now in the collection of the National Gallery of Canada, was purchased directly from the artist's grcat grandniece.

6 Jones, Life, 322-24; National Gallery of Canada file on Matilda Jones; Mrs. Vansittart to Miss Jones, 3 April 1832, Peter Jones fonds, Victoria University Library, University of Toronto.

7 Anne Verplanck, "The Social Meanings of Portrait Miniatures in Philadelphia, 1760-1820," American Material Culture: The Shape of the Field, eds Anne Smart Martin and J. Ritchie Garrison (Winterthur, DE and Knoxville, I'N, 1997), 196.

8 The statistic is based on a $25 \%$ cross-section of titles from Algernon Graves, The Royal Academy of Arts: A Complete Dictionary of Contributors and Their Work from Its Foundation in 1769 to 1904 (New York, 1972). After the advent of photography in 1839 miniature production began to decline.

9 Linda Nochlin's "The Imaginary Orient," Art in America (MayJune 1983), 46-59, has provided the paradigm for understanding European representations of Canada's First Nations. See Marcia Crosby, "The Construction of the Imaginary Indian," Vancouver Anthology: The Institutional Politics of Art, ed. Stan Douglas (Vancouver, 1991), 267-91, and Daniel Francis, The Imaginary Indian: The Image of the Indian in Canadian Culture (Vancouver, 1992).

10 Ruth Phillips, "Representation in the Miniature: Effigy, Toy, Model, Souvenir," in Phillips, Trading Identities: The Souvenir in Native North American Art from the Northeast, 1700-1900 (Montreal, 1998), 72-108.

11 Claude Levi-Strauss, The Savage Mind (London, 1966), 24-25; Susan Stewart, On Longing: Narratives of the Miniature, the Gigantic, the Souvenir, the Collection (Baltimore, 1984), 38.

12 Philips, Trading Identities, 73.

13 Smith, Sacred Feathers, 223.
14 The sweet and terrible blankness of Lady Hamilton's miniature of the Beothuk captivc Demasduit offers a somewhat different example of miniature portraiturc at the service of colonialism; see Kristina Huneault, "Always There: First Peoples and the Consolation of Miniature Portraiture in British North America," Art and the British Empire, eds Tim Barringer, Geoff Quilley, and Douglas Fordham (Manchester, forthcoming 2006).

15 The men's correspondence, exchanged over a thirteen-year period, is testament to their warm affection and mutual esteem. See Ayer Manuscript, Norton Papers, Newberry Library, Chicago (copies in the collection of Library and Archives (anada).

16 The introduction was likely effected though Mary Ansted, a mutual friend of Knight and Owen.

17 For an account of Knight's career, see Gcorge Williamson, Andrew and Nathaniel Plimer (London, 1903), 135-50.

18 Robert Owen to Mary Ansted, 20 January 1806, Ayer Manuscript. The copy of the miniature is now lost.

19 Norton, too, was pleased with the likeness, and ten years later, again through Owen and Ansted, he requested Knight to make a second miniature during a personal visit to England and Scotland. This copy remains unlocated. Mary Ansted to John Norton, 17 December 1815, John Norton Papers, Archives of Ontario.

20 Klinck, "Biographical Introduction," li. The painting, by Williams, is now lost.

21 Klinck, "Biographical Introduction," xvii.

22 William L. Stone, Life of Joseph Brant, 2 vols (New York, 1838) II, 426-28. See also Klinck, "Biographical Introduction," lvi.

23 Northumberland had commissioned an oil portrait of Brant by Gilbert Stuart, together with a miniature copy, which was treasured by the Brant family. Brant also owned a miniature of Francis Rawdon, later the Marquis of Hastings, given to him in friendship. See Milton Hamilton, "Joseph Brant: The Most Painted Indian," New York History 39, 2 (1958), 119-33, and Carolyn Thomas Foreman, Indians Abroad 1493-1938 (Norman, OK, 1943), 96.

24 Jones's likeness was taken by at least ten different artists. The second miniature by Matilda Jones scrved as the basis for an engraving by T.A. Dean, and a second engraving appears as the frontispicce of Jones's History of the Ojebway Indians (I.ondon, 1861). Ten calotypes of Jones (National Museum of Scotland) were taken in 1845 by David Octavius Hill and Robert Adamson, and are the earliest known photographs of a Nativc North American. Other recorded likenesses of Jones were done by $\mathrm{Mr}$ Steele in 1831 (Life, 305), by Mr Curlock in 1831 (Life, 308), by Mr Gush (Eliza Field diary), and by an unknown Glasgow painter (see note 25). He was also portrayed by his fiancée, Eliza Field.

25 Peter Jones to Eliza Field Jones, 4 Nov 1845, Peter Jones fonds.

26 Peter Jones to Eliza Field Jones, 12, 14, and 16 November 1845 , Peter Joncs fonds.

27 My thanks to Donald Smith for pointing this out.

28 Jones, Life, 305.

29 The image appears in the June 1833 volume.

30 Jones was "highly pleased" with the 300 prints he received to circulate in Canada. Jones, Life, 356.

31 Eliza Field diary, 19 July 1838, Peter Jones fonds. "Walked with 
Peter to Miss Jones, sat for the last time for my likeness - dined there."

32 Eliza Field diary, 14 and 15 February 1833, Peter Jones fonds. On the couple's relationship, see Donald Smith, "The Transatlantic Courtship of The Reverend Peter Jones," The Beaver 308, 1 (Summer 1977), 4-13.

33 Field diary, 19 February 1833.

34 Field diary, 31 March, 19 May, 26 May, and 6 June 1832.

35 Field diary, 9 June 1832, 14 February 1833.

36 Stewart, passim, especially 44 and 65-66.

37 Marcia Pointon, "'Surrounded with Brilliants': Miniature Portraits in Eighteenth-Century England," Art Bulletin 83, 1 (March 2001), 63.

38 Among this territory was the strip of land granted to Joseph Brant and the Mohawk loyalists in 1783 (Brant and Augustus Jones were to be fast friends), but the vast majority of terrain was slated for European settlement, and it now forms some of Canada's most valuable real estate, including the cities of Toronto and Hamilton.

39 Smith, Sacred Feathers, 30.

40 Smith, Sacred Feathers, 39.

41 Norton's birth date can now firmly be established as 16 December 1770. Church of Scotland, Parish Church of Crail, Old Parochial Registers, 1655-1857, http://www.familysearch.org/.

42 Vincente Rafael, Contracting Colonialism (Durham, NC, 1993), 210, cired in Douglas Robinson, Translation and Empire (Manchester, 1997), 5.

43 Robinson, Translation and Empire, 10.

44 Gayatri Spivak, "The Politics of Translation," in Lawrence Venuti, ed., Translation Studies Reader (London: Routledge, 2000), 400.

45 Klinck, "Biographical Introduction," 1.

46 N. Jaye Fredrickson and Sandra Gibb, The Covenant Chain: Indian Ceremonial and Trade Silver (Ottawa, 1980).

47 My thanks to Ruth Phillips and Guislaine Lemay for their input on Norton's dress. For a compelling analysis of the symbolic impact of transcultural dress, see Timothy Shannon, "Dressing for Success on the Mohawk Frontier: Hendrick, William Johnson, and the Indian Fashion," William and Mary Quarterly LIII, 1 (January 1996), 13-42.
48 Smith, Sacred Feathers, 104.

49 For analysis of the mise-en-abyme in relation to miniatures and the King's body, see Pointon, "Surrounded with Brilliants," 62-63.

50 Smith, Sacred Feathers, 104.

51 The original painting was by Gush, who undertook a series of portraits of prominent Methodists, including the one of Peter Jones that inspired Eliza Field to sit for her own portrait. That miniature (now lost) presumably served as the model for the engraving of Jones that appears in his History of the Ojebway Indians. Gush also painted Eliza's mother, prior to Eliza's departure for Canada. See Eliza Field's diary entries throughout February 1833.

52 Smich, Sacred Feathers, 139.

53 Smith, Sacred Feathers, 119, 156, 43, 154-55.

54 Copy of an address of the chiefs at Lake Huron To the Chieftans of England, 17 February 1831, delivered to King William IV by Peter Jones, Peter Jones fonds.

55 Peter Jones to Eliza Ficld Jones, 29 October 1845, Peter Jones fonds. Emphasis is present in the original text.

56 Pcter Jones to Eliza Field Jones, 30 January 1845, Peter Jones fonds. Emphasis is present in the original text.

57 Klinck, "Biographical Introduction," Ixxxvi.

58 J. McE. Murray, "John Norton," Papers and Records: Ontario Historical Society 37 (1945), 16.

59 Augustus Jones to Peter Jones, 30 March 1838, Peter Jones fonds.

60 Pointon, "Surrounded with Brilliants," 63.

61 Pointon, "Surrounded with Brilliants," 68.

62 On the history of Kaswentha, see Paul Williams and Curtis Nelson, "Kaswentha," For Seven Generations: An Information Legacy of the Royal Commission on Aboriginal Peoples, CD-ROM (Ottawa, 1996). For an analysis of Kaswentha in regard to contemporary constitutional politics, see Alan Cairns, Citizens Plus: Aboriginal Peoples and the Canadian State (Vancouver, 2000).

63 There is no "official" version of Kaswentha, or the Great Law of Peace; this translation of the wampum is by Onondaga subchief and Six Nations elder Huron Miller, and appears in the publication of the Native American Centre for the Living Arts, Turtle Quarterly (Winter 1980), 5. 